\title{
Carnets
}

Revue électronique d'études françaises de l'APEF

Première Série - 4 Numéro Spécial | 2012

Invasions \& Évasions

\section{In limine}

\section{Marc Fumaroli}

\section{OpenEdition}

Journals

Édition électronique

URL : http://journals.openedition.org/carnets/7206

DOI : 10.4000/carnets.7206

ISSN : 1646-7698

Éditeur

APEF

Édition imprimée

Date de publication : 1 juin 2012

Pagination : 11-12

\section{Référence électronique}

Marc Fumaroli, « In limine », Carnets [En ligne], Première Série - 4 Numéro Spécial | 2012, mis en ligne le 23 juin 2018, consulté le 24 septembre 2020. URL : http://journals.openedition.org/carnets/7206 ; DOI : https://doi.org/10.4000/carnets.7206

\section{(ब) $(1) \Theta$}

Carnets est mis à disposition selon les termes de la licence Creative Commons - Atribution - Pas d'utilisation commerciale 4.0 International. 
MARC FUMAROLI

C'est un grand honneur, mais aussi un grand bonheur, de me trouver aujourd'hui parmi les professeurs portugais de littérature française réunis dans cette célèbre villeuniversité de Coimbra.

Je n'évoquerai pas le long passé de dialogue entre nos deux littératures qui donne leurs titres de noblesse aux chaires que vous occupez et à la discipline que vous enseignez.

Je vous inviterai plutôt à regarder autour de nous et à nous demander quel sens nouveau revêt aujourd'hui l'enseignement de la langue et de la littérature françaises.

Aujourd'hui, au Portugal comme en France, l'empire sur l'éducation appartient à la télévision, à la vidéo, au portable, à l'internet, aux réseaux sociaux, aux marques de vêtement et d'accessoires qui proclament un pouvoir d'achat et surtout à la toute puissante publicité.

Dès l'enfance, le marché des technologies de communication et la prédication publicitaire conditionnent le consommateur à un conformisme de masse ou de groupe. Du soir au matin, on annonce la mort du livre, son asservissement à l'image numérique et on promet un monde global nouveau peuplé d'heureux consommateurs futuristes, débarrassés de leur propre mémoire, de leur propre imagination, et de leur propre jugement, mais greffés de gadgets tenant lieu des anciennes facultés de l'individu.

Naguère et autrefois, au temps de la civilisation certes très imparfaite du livre, enseigner une littérature étrangère, c'était développer les dons de ses étudiants, c'était un luxe très souhaitable et allant de soi. Aujourd'hui, c'est devenu une mission dangereuse et capitale pour la survie d'individus non atrophiés de leurs sens et de leurs facultés, non réduits au "choix rationnel" des économistes, mais exerçant pleinement leur jugement critique et leur jugement de goût. Plus le péril croît, plus la mobilisation est intense. Les images et leurs technologies sont omniprésentes et envahissantes. Utilisons leurs technologies pour révéler à nos étudiants les images cent fois plus éveilleuses des sens et de l'imagination que celles qu'on leur vend et dont on les bombarde.

Brisons la frontière qui a séparé trop souvent jusqu'ici l'histoire des arts et l'histoire des lettres et de la poésie. II se trouve que la littérature française, qui écrit une langue souvent évincée par le marché global, est de toutes les littératures la plus étroitement liée depuis le XVIle siècle à la poésie, à la fiction, à la critique et à la description d'art. Roger de Piles et Watteau, Diderot et Chardin, Baudelaire et Delacroix, Valéry et Degas. Ces couples forment de magnifiques contrepoids aux War Video games, au sitcoms télévisés, et ils sont 
au fond beaucoup plus attrayants que ces rivaux qui associent bande image vulgaire à bande son tonitruante.

II faut s'il est question, comme c'est votre cas, donner ce sens quasi missionnaire à la littérature française, apprendre, en se servant des nouveaux "médias", entre autres voies, à faire sentir aux jeunes gens et aux jeunes filles le gouffre qui sépare le monde commercial qui cherche à les aliéner, et le monde classique des lettres et des arts qui tend à les rendre libres et à multiplier la vérité de leur rapport au monde et à autrui. C'est devenu une mission d'apôtres laïcs que notre métier, notre recherche, notre enseignement d'une littérature qui, comme aucune autre, a pratiqué l'Ut pictura poesis. II y a plus de sens que jamais à enseigner le français et la littérature aujourd'hui. 